\title{
AKRUAL
}

Jurnal Akuntansi

http://fe.unesa.ac.id/ojs/index.php/akrl

\section{PENELITIAN TERAPAN EKONOMETRIKA DALAM SISTEM INFORMASI AKUNTANSI PERMODELAN TIME SERIES DATA PENJUALAN JASA SALON KENDARAAN BERMOTOR X DENGAN METODE ARIMA UNTUK MENINGKATKAN KUALITAS INFORMASI KINERJA DIVISI PENJUALAN}

\author{
Bonnie Soeherman \\ Ilmu Akuntansi Universitas Airlangga \\ Email: bee7179@yahoo.com \\ Artikel diterima: 31 Nepember 2012 \\ Terakhir direvisi: 18 Januari 2013
}

\begin{abstract}
Information is an absolute fuel to trigger the decision making process. Information failure can be fatal and impact on the future. The concept of accounting information system offered an alternative of how to design systems to produce effective information in efficient way. Historical financial accounting information was not adequate as a basis for strategic decision making. Accounting information should been complemented with information that has future orientation or predictive value. Therefore, this study tried to give new thought to minimize the gap in accounting information and decision-making through econometric or statistical techniques with pilot projects sold data modeling time series with ARIMA method. This research was applied and more emphased on aspects of practical value to the world than to enrich the theory by simply disassembling the variables. I found that future orientedinformation had better strategic value for decision making process.
\end{abstract}

Keywords: accounting information systems, decision, sales transaction, performance, control.

\section{PENDAHULUAN}

\section{Latar Belakang}

Dalam kitab Seni Perang Sun Zi disebutkan "Kenali diri sendiri, kenali pihak lain, seratus pertempuran, seratus kemenangan... Kenali cuaca, kenali dataran, maka kemenangan anda menjadi tak terbatas". Kutipan ini merupakan ungkapan filosofis yang mengandung esensi pentingnya informasi dalam pelaksanaan perang. Informasi merupakan dasar pengambilan segala keputusan. Informasi yang berkualitas tentu mudah mengantarkan seseorang metaih tujuannya. Jika ditelusuri, filosofi ini masih sangat relevan dengan dinamika sosial modern. Sejak zaman dahulu hingga saat ini, informasi tetap memegang peran kunci dalam sebuah pencapaian. 
Sejak Mei 2010 lalu, pemerintah Indonesia mengefektifkan UU Nomor 14 Tahun 2008 mengenai Keterbukaan Informasi Publik (Wedhaswary, 2010). Artinya, kita sedang hidup dalam era informasi. Saat ini, informasi merupakan unsur yang sangat penting. Dikatakan siapa yang menguasai informasi, dia yang menguasai dunia. Sama halnya dengan sebuah organisasi atau perusahaan. Informasi memegang peran kunci sebagai dasar pembuatan keputusan baik taktis maupun strategis. Disiplin akuntansi, khususnya sistem informasi akuntansi (SIA) muncul sebagai respon kebutuhan informasi yang berkualitas. Perusahaan-perusahaan berlomba membangun sistem informasi terbaik untuk meningkatkan kualitas keputusan yang berdampak pada performa masa depan. Sebut saja Amazon.com, sebuah perusahaan virtual yang menjual berbagai varian produk dari A sampai $\mathrm{Z}$ mampu melayani seluruh konsumen dari seluruh belahan dunia dalam waktu yang sangat cepat. Selain kualitas manajemen, kesuksesan Amazon.com juga sangat tergantung pada peran sistem informasi transaksi yang supercanggih (O'brien and Marakas, 2008).

Sebuah sistem informasi yang baik akan menghasilkan informasi yang baik pula. Sebaliknya, keterbatasan informasi justru akan menimbulkan inefisiensi hingga berakibat pada kesalahan pembuatan keputusan. Jika diperhatikan, perkembangan konsep sistem informasi akuntansi lebih bersifat historis. Artinya, lebih menekankan pada tindak evaluasi korektif terhadap data (transaksi) yang sudah terjadi. Padahal jika dikaji kembali, konsep informasi yang baik seharusnya mampu sebagai pegangan memprediksi langkah di masa depan, bukan hanya mengkoreksi data historis saja. Inilah yang sering menjadi gap dalam dunia sistem informasi akuntansi.

Melalui penelitian terapan ini, akan diberikan alternatif solusi terbaik penyediaan informasi yang berkualitas untuk mengimbangi pembuatan keputusan yang selama ini lebih berorientasi pada tindakan korektif saja (berdasarkan informasi akuntansi hostoris), namun juga tindakan preaktif. Berbagai metode ekonometrika telah dikembangkan untuk memfasilitasi kebutuhan ini. Secara khusus, penelitian ini menggunakan analisis data time series dengan metode ARIMA untuk membantu memprediksi dengan lebih akurat kondisi masa depan organisasi.

Penelitian ini mengambil rumusan masalah bagaimana permodelan time series data penjualan jasa salon kendaraan bermotor $\mathrm{X}$ dengan metode ARIMA untuk meningkatkan kualitas informasi kinerja divisi penjualan? Untuk memberikan penjelasan yang logis dan terstruktur, rumusan masalah tersebut dapat diperinci dalam subrumusan maslaah sebagai berikut:

1) Bagaimana sistem informasi siklus penjualan jasa salon kendaraan bermotor $X$ serta penilaian dan dasar pembuatan keputusan kinerja divisi penjualan?

2) Apa saja permasalahan yang muncul selama ini pada proses evalusai dan pembuatan keputusan kinerja divisi penjualan?

3) Bagaimana analisis dan permodelan time series data penjualan jasa salon kendaraan bermotor $\mathrm{X}$ ?

4) Bagaimana permodelan ARIMA dapat meningkatkan kualitas informasi kinerja divisi penjualan jasa salon kendaraan bermotor $\mathrm{X}$ ? 
Sejalan dengan rumusan masalah yang dihadapi, penelitian ini bertujuan untuk memberi feedback pada obyek penelitian tentang penyediaan permodelan time series data penjualan jasa salon kendaraan bermotor $\mathrm{X}$ sebagai penyeimbang informasi yang dibutuhkan dalam proses evaluasi dan pembuatan keputusan. Penelitian ini merupakan penelitian terapan yang lebih dikhususkan pada pemberian informasi lebih berkualitas bagi jasa salon kendaraan bermotor $\mathrm{X}$ yang diharapkan dapat mempertajam arah evaluasi dan pembuatan keputusan terkait kinerja divisi penjualan. Selain itu, penelitian ini diharapkan dapat memberi gambaran holistik mengenai penyediaan sistem informasi yang tidak hanya berfokus pada tindakan reaktif atas kejadian historis, namun juga diseimbangkan dengan tindakan kendali preaktif yang berorientasi pada masa depan. Pada akhirnya, diharapkan pula dapat memperkaya keilmuan akuntansi.

Penelitian ini membatasi permodelan pada data penjualan bulanan mulai bulan Januari tahun 2008 sampai bulan Desember tahun 2010 sebagai pilot project, mengingat upaya ini sebagai langkah awal perbaikan penyediaan informasi dalam pembuatan keputusan reaktif/ korektif dan preaktif. Selain itu, dipilihnya divisi penjualan karena divisi ini merupakan ujung tanduk jasa salon kendaraan bermotor $\mathrm{X}$ yang langsung berhubungan dengan konsumen, pemicu keuntungan utama.

\section{KAJIAN PUSTAKA}

\section{Sistem Informasi Akuntansi}

Sistem Informasi diartikan sebagai kumpulan komponen (data, perangkat keras dan lunak, prosedur, pengendalian internal, dan pengguna) yang saling berinteraksi dengan konstribusi peran uniknya yang bekerja sama untuk mencapai satu tujuan tertentu (Romney and Steinbart, 2010). Adapun secara khusus, tujuan dari sistem informasi akuntansi (SIA) adalah:

1) Mencatat dan mendokumentasikan data transaksi. Transaksi merupakan aktivitas timbal balik dalam hubungan give and get yang bernilai ekonomis, misalnya penjualan jasa, pembelian barang, penggajian karyawan, dan proses produksi yang mengkonsumsi biaya overhead, tenaga kerja, dan bahan baku.

2) Memproses data tersebut menjadi informasi yang berguna bagi pembuatan keputusan. Dalam SIA, data merupakan fakta sedangkan informasi merupakan hasil olahan data yang memiliki nilai dan dapat dipakai sebagai dasar pembuatan keputusan.

3) Menyediakan pengendalian internal yang tepat, seperti penyediaan fasilitas otorisasi, pemisahan fungsi, dan penyediaan dokumen yang memadai.

\section{Karakteristik Informasi}

Kualitas keputusan logis sangat ditentukan oleh kualitas informasi. Untuk itu, informasi yang dihasilkan harus berkualitas. Romney and Steinbart (2010) memberikan gambaran sederhana tentang kualitas informasi yang baik yang disebut juga sebagai karakteristik informasi yang berkualitas, yaitu: 
1) Relevan, mengurangi ketidakpastian, mampu meningkatkan kemampuan prediksi, atau memantapkan/mengkoreksi harapan sebalumnya.

2) Dapat dipercaya, bebas dari kesalahan dan mampu merepresentasi kejadian/ transasksi.

3) Lengkap, tidak mengabaikan hal-hal yang penting even atau aktivitas yang hendak dinilai.

4) Tepat waktu, menyediakan informasi sesuai kurun waktu yang diinginkan terkait dengan pembuatan keputusan.

5) Mudah dipahami, disajikan dalam bentuk yang berguna dan jelas.

6) Dapat diverisikasi, menghasilkan output yang sama ketika diproses dengan cara sama oleh lebih dari satu orang yang berbeda.

\section{Siklus Penjualan}

Kebutuhan informasi melekat pada seluruh lini atau divisi dalam sebuah perusahaan. Secara khusus, penelitian ini mengangkat divisi penjualan sebagai obyek penelitian. Siklus penjualan merupakan rangkaian aktivitas mulai dari pemesanan produk (barang/jasa) oleh konsumen, merespon pesanan dan mengirimkan pesanan, dan penagihan dan penerimaan uang. Gambar 1 dibawah merupakan gambar bagan alur transaksi penjualan secara umum.

\section{Kinerja dan Pengendalian}

Seperti telah disebutkan bahwa salah satu tujuan dari SIA adalah untuk menyediakan pengendalian internal. Konsep pengendalian merupakan bagian dari aktivitas manajemen umum. Pengendalian manajemen merupakan proses perancangan instrumen-instrumen yang ditujukan untuk membatasi tindakan karyawan agar tetap fokus pada tujuan organisasi (Merchant and Stede, 2003). Dari perspektif waktu, pengendalian dapat dibedakan menjadi tiga, yaitu preaktif, detektif, dan reaktif. Pengendalian preaktif dilakukan sebelum kejadian yang menyimpang terjadi sebagai tindak antisipatif, misalnya menelaah anggaran sebelum disahkan, pemisahan otoritas/ fungsi, dan menyediakan penguncian data melalui password. Pengendalian detektif dilakukan pada saat terjadi penyimpangan, misalnya pada sistem produksi Toyota yang dapat diberhentikan setiap saat oleh operator ketika diketahui terjadi kesalahan. Pengendalian reaktif merupakan pengendalian yang dilakukan setelah terjadi penyimpangan dan biasanya proses evaluasi ini dilakukan pada akhir periode, misalnya analisis varians.

Jadi, dengan pengendalian yang baik diharapkan apa yang diinginkan perusahaan dapat dilaksanakan oleh setaip lini beserta personelnya. Dengan kata lain, pengendalian yang baik bertujuan untuk mencapai tujuan yang baik dengan terus menjaga performa terbaik divisinya.

\section{Keterbatasan Fokus Sistem Informasi Akuntansi}

Hansen and Mowen (2005) menjelaskan salah satu karakteristik akuntansi keuangan yang lebih fokus pada aspek historis atau masa lalu, atas kejadian yang 
sudah terjadi. Sehingga pengendalian yang lebih efektif dilakukan adalah bersifat reaktif. Selain lama, proses analisis dan pecarian akar masalah relative lebih lama dan sangat dimungkinkan dampak dari penyimpangan sudah terlanjur terlipatganda dan baru disadari pada akhir periode. Orientasi akuntansi konvensional inilah yang kurang cukup kuat untuk menjadi satu-satunya dasar pembuatan keputusan masa depan.

Untuk mengotimalkan kualitas informasi, maka informasi akuntansi keuangan hostoris perlu diimbangi dengan informasi yang lebih berorientasi pada masa depan, prediktif, dan preaktif. Seperti pepatah "bawalah payung sebelum hujan" dan "lebih baik mencegah daripada mengobati" nampaknya sudah menjadi jiwa dari bentuk pengendalian preaktif. Untuk itulah penelitian ini berusaha mengisi gap tersebut dengan mengintegrasikan konsep ekonometrika dalam akuntansi melalui permodelan time series dengan metode ARIMA.

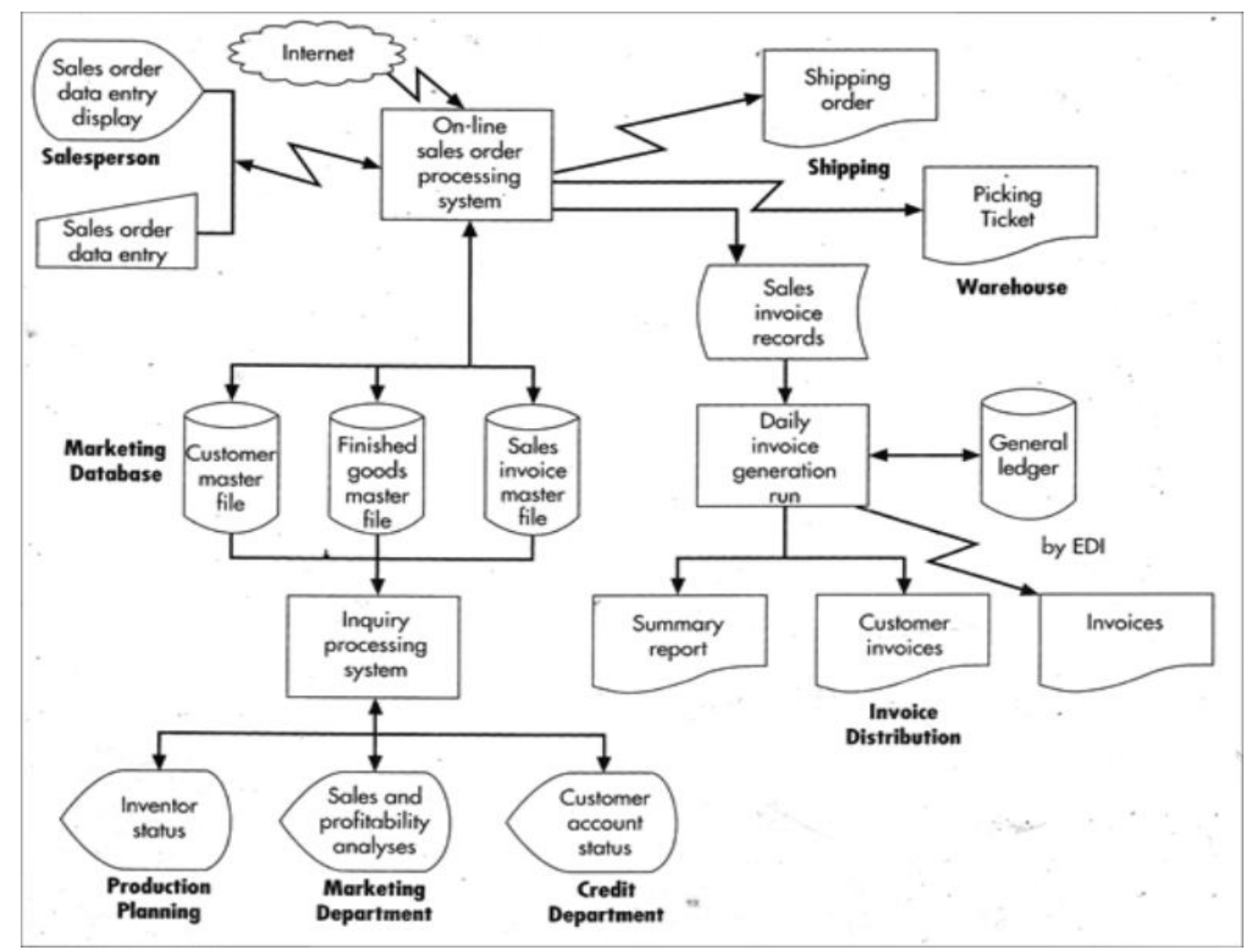




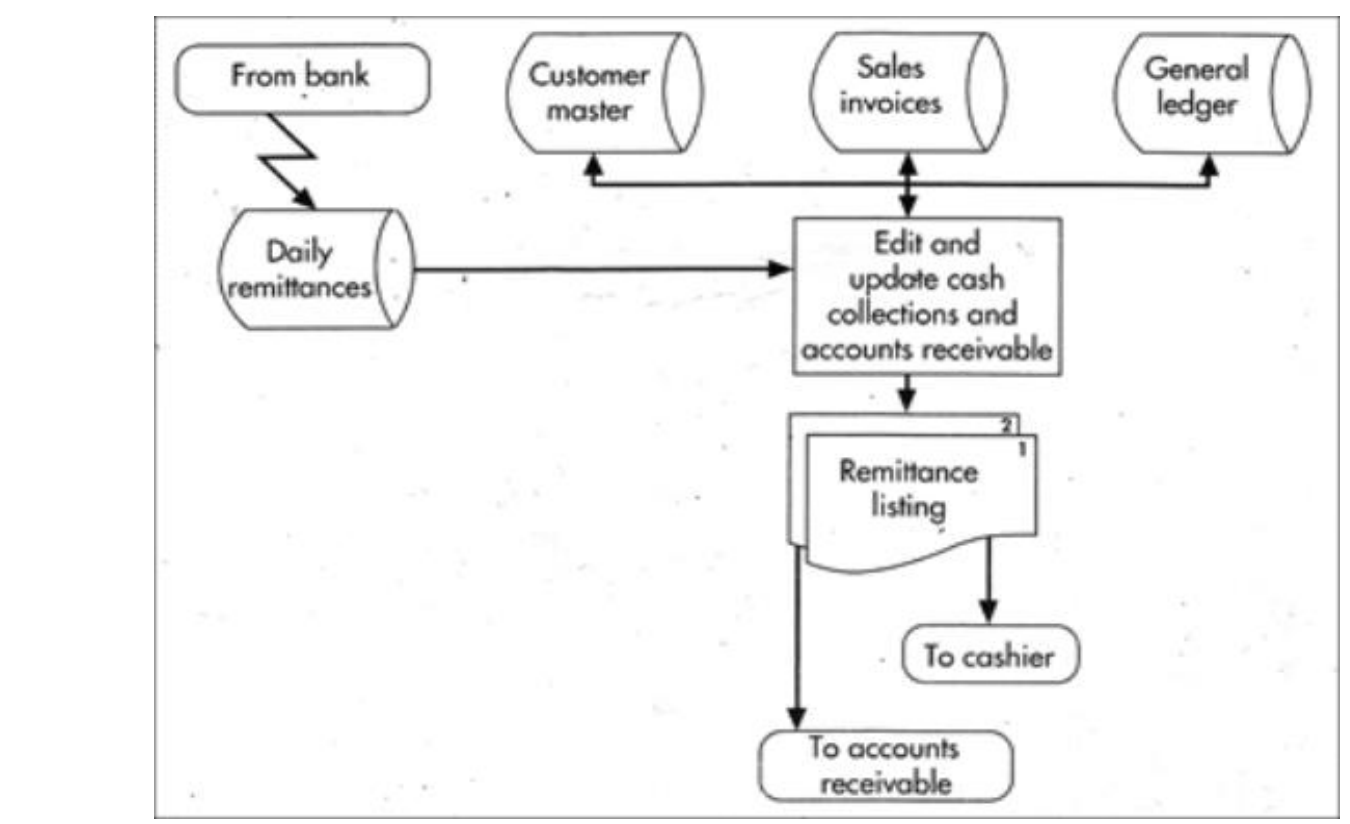

Sumber: Romney \& Steinbart (2009)

\section{Gambar 1. Penerimaan Order Hingga Penerimaan Uang}

\section{Permodelan Time Series ARIMA}

Awalnya, model Autoregressive Integrated Moving Average (ARIMA) merupakan salah satu alat dalam bidang statistika. Namun seiring kompleksitas di berbagai bidang, mulailah model ini dikembangkan dan diaplikasikan di bidang non statistika, seperti di bidang ekonometrika dan manajemen keuangan seperti penelitian-penelitian yang dilakukan oleh Achmad (2004), Suprapto (2005) tentang analisis teknikal harga saham dan kurs. Di bidang lain, ARIMA juga sudah makin meluas kegunaannya seperti penelitian yang dilakukan oleh Istiqomah (2006) dan Umi di bidang manajemen.

ARIMA seringkali disebut metode runtuk waktu Box-Jenkins yang lebih tepat digunakan untuk keperluan peramalan jangka pendek. ARIMA mengabaikan variabel independen yang cocok untuk menganalisis data dalam time series yang saling berhubungan. Saat ini, kecanggihan teknologi komputer sudah memungkinkan siapa saja untuk mengolah data dengan metode ARIMA seperti Minitab, SPSS, atau EViews. Proses pengolahan data dengan ARIMA harus memperhatikan konsep stasioneritas dan nonstasioneritas. Hal yang perlu diperhatikan adalah bahwa kebanyakan deret berkala bersifat nonstasioner dan bahwa aspek-aspek AR dan MA dari model ARIMA hanya berkenaan dengan deret berkala yang stasioner. Stasioneritas artinya tidak ada lagi pertumbuhan atau penurunan pada data (horizontal sepanjang sumbu waktu).

Jika ditemukan time series yang tidak stasioner, maka harus distasionerkan dengan teknik differencing atau menghitung perubahan atau selisih nilai observasi hinga melakukan transformasi logaritma. Model ARIMA umumnya dikategorikan ke 
dalam 3 kelompok, yaitu: model autoregressive (AR), moving average (MA), dan model campuran ARIMA (autoregresive moving average) yang mempunyai ciri-ciri khusus dua model pertama. Secara umum ARIMA dinotasikan dengan ARIMA $(\mathrm{p}, \mathrm{d}, \mathrm{q})$ dimana $\mathrm{p}, \mathrm{d}$, dan $\mathrm{q}$ secara berurut menyatakan orde dari auto-regression, integration (differencing), dan moving average. Model ARIMA juga sangat relevan digunakan dalam analisis data musiman (Wahana Statistika, 2011).

\section{Peran Ekonometrika dalam Dunia Akuntansi}

Sebagai bagian dari ekonomi, tentu saja akuntansi banyak terpengaruh, mengadopsi, dan saling ketergantungan dengan ekonomi secara umum. Begitu pula dengan konsep ekonometrika yang seharusnya melekat erat dengan dunia akuntansi dengan tidak terbatas hanya pada pengolahan data saham dan kurs saja dalam konteks akuntansi keuangan. Pengolahan data statistik, khususnya untuk forecasting yang tepat mampu meningkatkan kualitas informasi sehingga keputusan manajemen yang diambilpun bisa lebih berkualitas karena tidak melulu berorientasi pada masa lampau tapi juga pada masa depan. Dari berbagai ulasan literatur di atas dapat digambarkan skema keterkaitan seperti yang terlihat pada gambar 2 .

\section{METODE PENELITIAN}

Penelitian ini secara khusus berusaha memandang penyelesaian masalah secara komprehensif, tidak dibatasi oleh paradigma kualitatif maupun kuantitatif. Penelitian terapan ini lebih mengutamakan kebergunanaan dan kebermanfaatan dalam dunia praktik. Adapun teknik pengumpulan data yang dilakukan tidak terbatas pada dua paradigm penelitian pada umumnya, namun lebih pada penggabungan untuk mencari kombinasi yang benar-benar memberi nilai bagi dunia bisnis.

Teknik pengumpulan data yang digunakan mulai dari observasi tanpa terlibat langsung dan wawancara mendalam dengan pemilik dan supervisor lapangan. Selain itu, juga digunakan teknik dokumentasi prosedur transaksi dan laporan-laporan terkait siklus penjualan. Setelah menemukan akar masalah terkait dengan penyediaan informasi dan pembuatan keputusan, dilakukan komputasi statistika untuk membangun model dengan metode ARIMA (dengan aplikasi EViews) sebagai dasar forecasting dan pembuatan keputusan yang lebih tepat. Penggabungan teknik ini digunakan untuk meningkatkan validitas data serta menghasilkan solusi yang lebih bisa diterapakan (applicable) bagi dunia praktik.

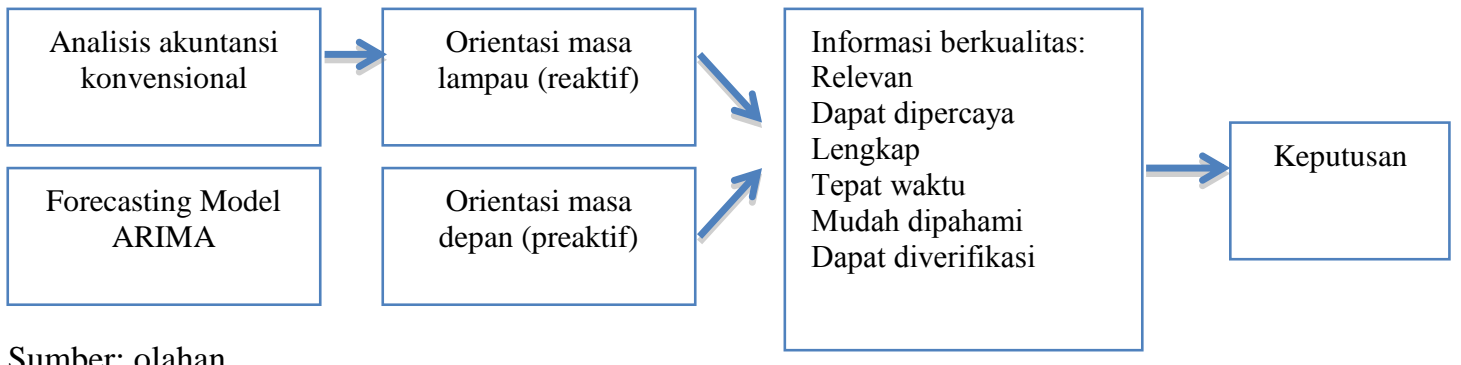

Gambar 2. Skema Keterkaitan Konsep 


\section{PEMBAHASAN}

Bagian ini akan menjawab subrumusan masalah yang telah ditetapkan sebalumnya, yaitu bagaimana sistem informasi siklus penjualan jasa salon kendaraan bermotor $\mathrm{X}$ serta penilaian dan dasar pembuatan keputusan kinerja divisi penjualan; apa saja permasalahan yang muncul selama ini pada proses evalusai dan pembuatan keputusan kinerja divisi penjualan; bagaimana analisis dan permodelan time series data penjualan jasa salon kendaraan bermotor X; dan bagaimana permodelan ARIMA dapat meningkatkan kualitas informasi kinerja divisi penjualan jasa salon kendaraan bermotor $\mathrm{X}$.

\section{Siklus Penjualan dan Permasalahan Jasa Salon Kendaraan Bermotor X}

Secara umum, penjualan jasa salon $\mathrm{X}$ dapat dikelompokkan ke dalam dua kateogri, yaitu penjualan jasa cuci kendaraan dan penjualan aksesoris seperti parfum, oli, aki, dan sebagainya. Adapun prosedur transaksi untuk penjualan jasa hasil observasi dan wawancara dengan pemilik adalah sebagai berikut:

Konsumen datang menuju operator lapangan untuk menyampaikan kebutuhan jasa kepada admin lapangan mencatatnya dalam form surat perintah kerja (SPK) secara komputerisasi. Kemudian, admin memberikan SPK pada operator lapangan yang menunggu antrian kerja. Setelah layanan selesai, operator menyampaikan pada kasir dan segera konsumen melakukan pembayaran di kasir. Proses ini juga dilakukan secara komputerisasi dan terintegrasi dengan proses pembuatan SPK. Jadi, setiap input data SPK, secara otomatis akan terupdate dalam database pusat dan dapat diakses oleh kasir dengan tingkatan pengguna sebagai pembaca. Dokumen ini yang mendasari pencetakan nota penjualan dan pembuatan laporan penjualan harian.

Walaupun laporan penjualan sudah tersedia harian, namum dalam wawancara bersama pemilik dan supervisor masih ditemukan dua permasalahan utama, yaitu keputusan investasi dan pengalokasian biaya seperti biaya marketing yang seringkali terlalu berlebihan. Masalah ini terjadi akibat pembuatan keputusan manajemen yang mengutakaman intuisi, spekulasi tanpa prediksi masa depan yang matang. Mereka hanya mengandalkan analisis dan evaluasi masa lalu tanpa melihat prediksi ke depan dengan cermat. Selain neraca tampak tidak sehat, akibat pola pembuatan keputusan ini juga berdampak pada tidak terkendalinya arus kas dan laporan laba rugi yang berfluktuatif tanpa pola yang jelas.

\section{Analisis dan Permodelan Time Series dengan ARIMA}

Untuk memberikan solusi, saya mencoba menangkap data penjualan bulanan mulai Januari 2008 hingga Desember 2010 sebagai proyek percontohan untuk memberikan pertimbangan lebih akurat dalam pembuatan keputusan. Berikut data penjualan jasa salon kendaraan bermotor $\mathrm{X}$ : 
Tabel 1. Penjualan Jasa Salon Kendaraan Bermotor X

\begin{tabular}{rlrrrrr}
\hline Tahun & Periode & Pendapatan & Tahun & Pendapatan & Tahun & Pendapatan \\
\hline 2008 & Januari & 176.733 .750 & 2009 & 159.139 .650 & 2010 & 169.661 .098 \\
& Februari & 159.227 .350 & & 150.946 .750 & & 167.897 .331 \\
& Maret & 181.553 .050 & & 163.409 .068 & 170.538 .473 \\
& April & 171.766 .850 & & 151.663 .400 & 171.145 .320 \\
& Mei & 171.836 .605 & 154.208 .349 & 164.757 .246 \\
& Juni & 150.502 .800 & 149.004 .600 & 162.723 .360 \\
& Juli & 197.116 .274 & 160.059 .160 & 177.224 .646 \\
& Agustus & 202.830 .550 & 188.290 .060 & 174.930 .025 \\
& September & 215.365 .520 & & 185.782 .435 & 190.421 .454 \\
& Oktober & 206.986 .786 & & 181.041 .790 & & 213.038 .249 \\
& November & 176.452 .260 & & 175.859 .090 & 173.782 .083 \\
Desember & 182.779 .040 & & 172.745 .482 & & 189.489 .031 \\
\hline
\end{tabular}

Sumber: Data perusahaan (diolah)

Dengan plot grafik, dapat dilihat bahwa jasa salon $X$ ternyata memiliki pola musiman dalam perolehan pendapatan. Hal ini telah dikonfirmasikan pada supervisor bahwa bisnis demikian memang mengikuti pola konsumsi masyarakat Madura, dimana pada bulan-bulan Agustus hingga Oktober selain merayakan lebaran, sebagian besar dari mereka juga sedang menikmati hasil panen tembakau. Di saat lebaran, sangat ramai pengunjung karena pada umumnya, pemilik mobil ingin tampil prima dalam mengunjungi sanak saudara, termasuk mobil yang disalonkan terlebih dahulu. 


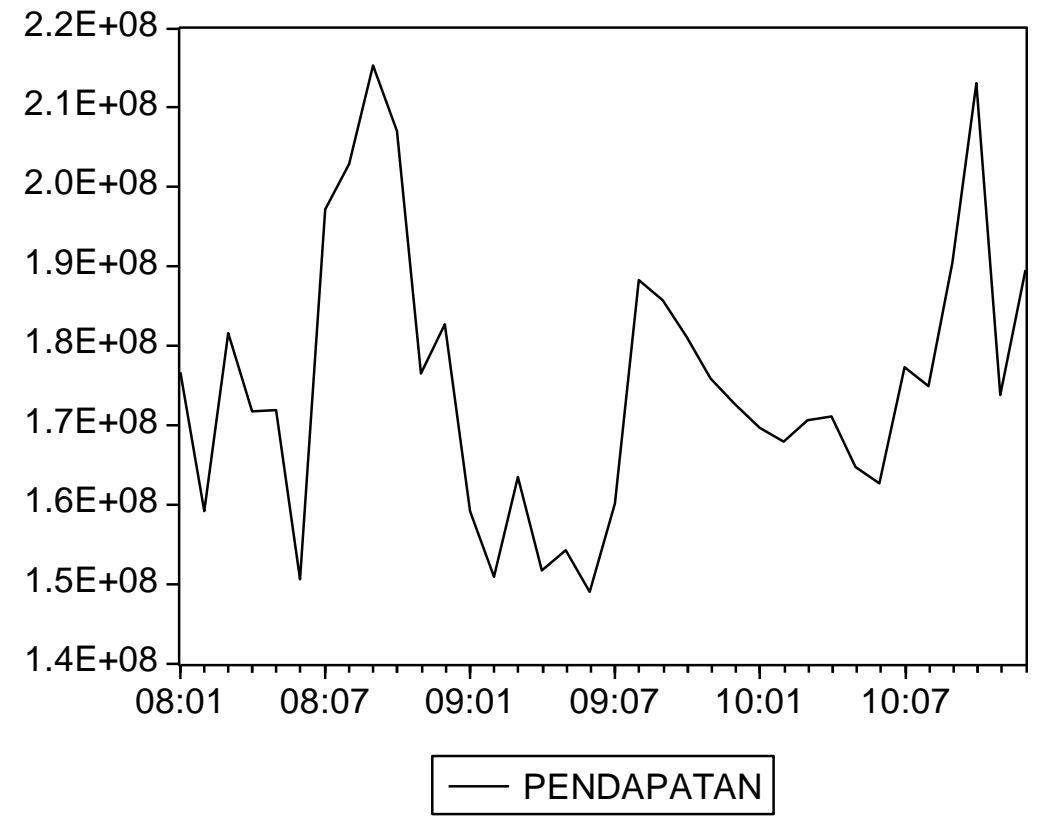

Sumber: internal perusahaan (diolah)

\section{Gambar 3. Plot Data Penjualan 2008-2010}

Dari konfirmasi juga ditemukan bahwa secara umum, performa pendapatan tahun 2009 mengalami penurunan. Hal ini diakibatkan munculnya pesaing serupa menawarkan promo-promo bombastis, termasuk fasilitas ruang karaoke dengan wanita cantik yang siap menemani bernyanyi. Sekilas, grafik pendapatan jasa salon $\mathrm{X}$ cukup baik, namun ketika dibandingkan dengan laporan keuangan, performa ini akan tertutup dengan aktivitas pembiayaan dan investasi yang sangat tidak sehat. Hal ini diakibatkan pihak manejemen merasa rabun dalam melihat masa depan, sehingga mereka lebih memilih jalan konservatis dengan mengeluarkan investasi dan biaya yang berlebihan untuk menarik konsumen padahal belum tentu apa yang difasilitaskan sesuai dengan ekspektasi konsumen atau bahkan terlalu melebihi ekspektasi konsumen, contohnya konsumen mengharapkan skor 3 tapi perusahaan memberinya 30. Memang efektif namun sangat tidak efisien. Itulah mengapa permodelan ini akan sangat membantu pihak manajemen dalam manajemen biaya dalam rangka menjaga kesehatan dan keseimbangan dengan forecast penjualan ke depan yang akurat.

Tahap berikutnya, dilakukan Unit Root Test dengan kategori Level dan Trend Intercept untuk menguji stasioneritas dan berikut hasilnya: 
Tabel 2. Unit Root Test

Null Hypothesis: PENDAPATAN has a unit root

Exogenous: Constant, Linear Trend

Lag Length: 0 (Automatic based on SIC, MAXLAG=9)

\begin{tabular}{lcc}
\hline & t-Statistic & Prob.* \\
Augmented Dickey-Fuller test statistic & -3.054747 & 0.1327 \\
Test critical values: $\quad$ 1\% level & -4.243644 & \\
5\% level & -3.544284 & \\
10\% level & -3.204699 & \\
*MacKinnon (1996) one-sided p-values. & &
\end{tabular}

Augmented Dickey-Fuller Test Equation

Dependent Variable: D(PENDAPATAN)

Method: Least Squares

Date: 01/04/80 Time: 01:00

Sample(adjusted): 2008:02 2010:12

Included observations: 35 after adjusting endpoints

\begin{tabular}{|c|c|c|c|c|}
\hline Variable & Coefficient & Std. Error & t-Statistic & Prob. \\
\hline PENDAPATAN(-1) & -0.459955 & 0.150571 & -3.054747 & 0.0045 \\
\hline $\mathrm{C}$ & 79257003 & 26806267 & 2.956659 & 0.0058 \\
\hline @TREND(2008:01) & 86251.01 & 253633.6 & 0.340062 & 0.7360 \\
\hline $\mathrm{R}$-squared & 0.227573 & Mean dependent var & & 364436.6 \\
\hline Adjusted R-squared & 0.179296 & S.D. dependent var & & 16727354 \\
\hline S.E. of regression & 15153760 & Akaike info criterion & & 35.98721 \\
\hline Sum squared resid & $7.35 \mathrm{E}+15$ & Schwarz criterion & & 36.12053 \\
\hline Log likelihood & -626.7762 & F-statistic & & 4.713934 \\
\hline Durbin-Watson stat & 1.996014 & Prob(F-statistic) & & 0.016059 \\
\hline
\end{tabular}

Sumber: data telah diolah

Dari tabel Augmented Dickey-Fuller test statistic dapat diketahui bahwa data sudah stasioner pada tingkat 5\%. Ini berarti dapat dilakukan proses berikutnya untuk menguji Autokolerasi dan berikut adalah hasilnya: 
Tabel 3. Uji Autokolerasi melihat AC dan PAC

\begin{tabular}{|c|c|c|c|c|c|c|c|}
\hline Autocorrelation & Partial Cor & relation & & $\mathrm{AC}$ & PAC & Q-Stat & Prob \\
\hline 1 & 1 & $\square$ & 1 & 0.530 & 0.530 & 10.970 & 0.001 \\
\hline 1 & 10 & 1 & 2 & 0.330 & 0.069 & 15.364 & 0.000 \\
\hline 1 & $1 \square$ & 1 & 3 & 0.026 & -0.243 & 15.392 & 0.002 \\
\hline 1 ᄃ & 1 문 & 1 & & -0.195 & -0.211 & 17.023 & 0.002 \\
\hline $1 \square$ & 1 & 1 & & -0.244 & -0.006 & 19.657 & 0.001 \\
\hline$\square$ & 1 口 & 1 & & -0.354 & - 0.190 & 25.385 & 0.000 \\
\hline 1 & 1 边 & 1 & & -0.338 & -0.134 & 30.782 & 0.000 \\
\hline 1 & 1 & 1 & & -0.275 & -0.046 & 34.470 & 0.000 \\
\hline । & 10 & 1 & & -0.212 & -0.092 & 36.751 & 0.000 \\
\hline 10 & 1 & 1 & 10 & -0.048 & 0.014 & 36.873 & 0.000 \\
\hline & & 1 & 11 & 0.157 & 0.174 & 38.224 & 0.000 \\
\hline । & 10 & 1 & 12 & 0.290 & 0.087 & 43.008 & 0.000 \\
\hline । & 10 & 1 & 13 & 0.259 & -0.136 & 46.984 & 0.000 \\
\hline 1 1 & 1 당 & 1 & 14 & 0.118 & -0.166 & 47.845 & 0.000 \\
\hline 101 & 1 든 & 1 & 15 & -0.068 & -0.157 & 48.146 & 0.000 \\
\hline 101 & 1 & I & 16 & -0.109 & 0.042 & 48.954 & 0.000 \\
\hline
\end{tabular}

Dependent Variable: D(PENDAPATAN)

Method: Least Squares

Date: 01/04/80 Time: 00:58

Sample(adjusted): 2008:03 2010:12

Included observations: 34 after adjusting endpoints

Convergence achieved after 19 iterations

Backcast: 2008:02

\begin{tabular}{rrlrr}
\hline \hline \multicolumn{1}{c}{ Variable } & Coefficient & \multicolumn{1}{c}{ Std. Error } & t-Statistic & Prob. \\
\hline C C & 889359.0 & 3016694. & 0.294813 & 0.7701 \\
MA(1) & -0.726076 & 0.128479 & -5.651331 & 0.0000 \\
\hline \hline R-squared & 0.930699 & 0.068045 & 13.67776 & 0.0000 \\
Adjusted R-squared & 0.168949 & Mean dependent var & 890049.4 \\
S.E. of regression & 0.115333 & S.D. dependent var & 16682952 \\
Sum squared resid & 15691443 & Akaike info criterion & 36.05923 \\
Log likelihood & $7.63 \mathrm{E}+15$ & Schwarz criterion & 36.19391 \\
Durbin-Watson stat & -610.0069 & F-statistic & & 3.151079 \\
\hline \hline Inverted AR Roots & 2.420949 & Prob(F-statistic) & & 0.056785 \\
Inverted MA Roots & -.73 & & & \\
\hline \hline
\end{tabular}

Sumber: data telah diolah 
Dari pengolahan di atas dapat dilihat bahwa model ini memenuhi kategori AR1 MA1 sehingga model ARIMA dapat dipergunakan. Dengan run model, dapat ketahui bahwa model time series untuk jasa salon $\mathrm{X}$ adalah sebagai berikut:

Estimation Command:

\section{LS D(PENDAPATAN) AR(1) MA(1) C}

Estimation Equation:

$\mathrm{D}($ PENDAPATAN $)=\mathrm{C}(1)+[\mathrm{AR}(1)=\mathrm{C}(2), \mathrm{MA}(1)=\mathrm{C}(3), \mathrm{BACKCAST}=2008: 03]$

Substituted Coefficients:

$\mathrm{D}(\mathrm{PENDAPATAN})=889358.9799+[\mathrm{AR}(1)=-$

$0.7260758182, \mathrm{MA}(1)=0.9306993909, \mathrm{BACKCAST}=2008: 03]$

\section{Implikasi Manajerial Permodelan ARIMA}

Permodelan ARIMA ini diharapkan dapat meningkatkan akurasi keputusan yang diambil karena adanya keseimbangan antara orientasi pada masa lalu dan masa depan, selain itu juga akan menciptakan keseimbangan bentuk kendali reaktif dan preaktif. Dengan mengetahui prediksi masa depan, maka akan lebih tepat pula keputusan terkait dengan akun-akun krusial. Selain itu, penggenapan orientasi ini juga sangat sesuai dengan harapan kualitas informasi yang baik, khususnya terkait dengan karakteristik relevan, dapat dipahami, tepat waktu, dan mudah dipahami. Konsep relevan berhubungan erat dengan kemampuan informasi memberi modal berpikir tentang prediksi. Hanya mengandalkan laporan keuangan masa lampau tentu sangat tidak memadai. Tentunya, dengan permodelan forcasting dakan mampu meminimalkan gap tersebut. Begitu pula dengan aspek ketepatan waktu, permodelan ini akan sangat relevan dalam hal waktu, mengingat orientasinya yang lebih pada masa depan. Walaupun masa depan tidak $100 \%$ bisa diprediksi, setidaknya sekian persen kepastian sudah ada di tangan manajemen. Permodelan berbasis statistika tentu saja akan sangat memenuhi syarat verifikasi. Kendalam aplikasi statistik seperti EViews tentunya akan sangat membantu penyediaan informasi dalam format grafis yang lebih mudah dipahami seperti dalam proses investigasi hasil plot data.

Selama input (data) benar dan diproses dengan prosedur yang benar, hasilnya pasati akan benar karena berlakukan prinsip garbage in, garbage out (GIGO) dalam dunia komputer. Hal ini akan meningkatkan kualitas informasi yaitu dapat diverifikasi. Keberhasilan implementasi pilot project ini nantinya diharapkan dapat diperluas aplikasinya pada divisi-divisi di luar penjualan sehingga secara 
keseluruhan, proses pembuatan keputusan dapat lebih akurat dan berperhitungan, tidak sekadar intuisi atau spekulasi tingkat tinggi.

\section{SIMPULAN}

Saat ini, informasi merupakan unsur yang sangat penting. Informasi memegang peran kunci sebagai dasar pembuatan keputusan baik taktis maupun strategis. Disiplin akuntansi, khususnya SIA muncul sebagai respon kebutuhan informasi yang berkualitas. Sebuah sistem informasi yang baik akan menghasilkan informasi yang baik pula. Sebaliknya, keterbatasan informasi justru akan menimbulkan inefisiensi hingga berakibat pada kesalahan pembuatan keputusan. Jika diperhatikan, perkembangan konsep sistem informasi akuntansi lebih bersifat historis. Artinya, lebih menekankan pada tindak evaluasi korektif terhadap data (transaksi) yang sudah terjadi. Padahal jika dikaji kembali, konsep informasi yang baik seharusnya mampu sebagai pegangan memprediksi langkah di masa depan, bukan hanya mengkoreksi data historis saja. Inilah yang sering menjadi gap dalam dunia sistem informasi akuntansi. Berbagai metode ekonometrika telah dikembangkan untuk memfasilitasi kebutuhan ini. Secara khusus, penelitian ini menggunakan analisis data time series dengan metode ARIMA untuk membantu memprediksi dengan lebih akurat kondisi masa depan organisasi.

Sebagai bagian dari ekonomi, tentu saja akuntansi banyak terpengaruh, mengadopsi, dan saling ketergantungan dengan ekonomi secara umum. Begitu pula dengan konsep ekonometrika yang seharusnya melekat erat dengan dunia akuntansi dengan tidak terbatas hanya pada pengolahan data saham dan kurs saja dalam konteks akuntansi keuangan. Pengolahan data statistik, khususnya untuk forecasting yang tepat mampu meningkatkan kualitas informasi sehingga keputusan manajemen yang diambilpun bisa lebih berkualitas karena tidak melulu berorientasi pada masa lampau tapi juga pada masa depan. Atmosfer demikian sangat mudah mengkondisikan para pengambil keputusan tidak lagi banyak melirik data lampau, tapi lebih mengandalkan intuisi atau spekulasi dengan pembenaran masa depan tidak dapat diprediksi.

Permodelan ARIMA ini diharapkan dapat meningkatkan akurasi keputusan yang diambil karena adanya keseimbangan antara orientasi pada masa lalu dan masa depan, selain itu juga akan menciptakan keseimbangan bentuk kendali reaktif dan preaktif. Dengan mengetahui prediksi masa depan, maka akan lebih tepat pula keputusan terkait dengan akun-akun krusial. Selain itu, penggenapan orientasi ini juga sangat sesuai dengan harapan kualitas informasi yang baik, khususnya terkait dengan karakteristik relevan, dapat dipahami, tepat waktu, dan mudah dipahami. 


\section{DAFTAR PUSTAKA}

Hansen, Don \& Mowen, Maryanne, Management Accounting, $7^{\text {th }}$ ed., Thomson Wadsworth.

Istiqomah, 2006, Aplikasi Model Arima Untuk Forecasting Produksi Gula Pada PT. Perkebunan Nusantara Ix (Persero), Aplikasi Model Arima Untuk Forecasting Produksi Gula Pada Pt. Perkebunan Nusantara IX (Persero.

Merchant, Kenneth A. \& Stede, Win A. Van, 2003, Management Cotrol Systems, Performance Measurement, Evaluation and Incentives, Prentice Hall.

O’Brien, James \& Marakas, George, 2008, Management Information Systems $9^{\text {th }}$ ed., McGraw-Hill/Irwin.

Romney, Marshall B. \& Steinbart, Paul J., 2009, Accounting Information Systems, 11/E, Prentice Hall.

Rosyiidah Umi, K., Diah Taukidha, Sitahrini, Dwi, Permodelan ARIMA dalam Peramalan Penumpang Kereta Api pada Daerah Operasi IX Jember.

Teguh Suprapto, Adi (2005) Peramalan Kurs Rupiah Terhadap Dolar Amerika Dengan Menggunakan Model ARIMA Studi Empiris Kurs Harian Rp/ US\$ 24/01/2001 - 30/06/2005, koleksi Universitas Diponegoro.

Wahana Statistika, 2001, Autoregressive Intregated Moving Average, situs: http://www.wahana-statistika.com/analisis/analisis-time-series/112-arimaautoregressive-integrated-moving-average.html

Wedhaswary, Inggried Dwi, 2010, Masuki Era Keterbukaan Informasi Publik, situs: http://nasional.kompas.com/read/2010/04/30/20510043/Masuki.Era.Keterbuka an.Informasi.Publik

Yani, Achmad (2004) Analisis Teknikal Harga Saham Dengan Metode ARIMA (Studi Pada IHSG Di Bursa Efek Jakarta), koleksi Universitas Diponegoro. 